Vapor pressures of 1,3-dialkylimidazolium bis(trifluoromethylsulfonyl)imide ionic liquids with long alkyl chains

Marisa A. A. Rocha', João A. P. Coutinho, and Luís M. N. B. F. Santos'

Citation: The Journal of Chemical Physics 141, 134502 (2014); doi: 10.1063/1.4896704

View online: http://dx.doi.org/10.1063/1.4896704

View Table of Contents: http://aip.scitation.org/toc/jcp/141/13

Published by the American Institute of Physics

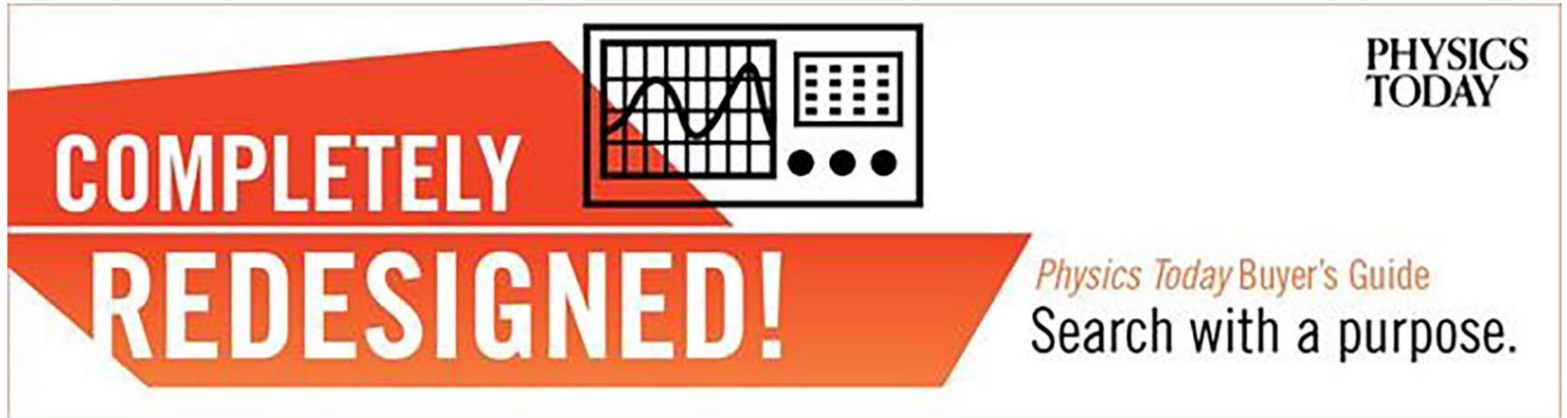




\title{
Vapor pressures of 1,3-dialkylimidazolium bis(trifluoromethylsulfonyl)imide ionic liquids with long alkyl chains
}

\author{
Marisa A. A. Rocha, ${ }^{1,2, a)}$ João A. P. Coutinho, ${ }^{3}$ and Luís M. N. B. F. Santos ${ }^{1, a)}$ \\ ${ }^{1}$ Centro de Investigação em Química, Departamento de Química e Bioquímica, Faculdade de Ciências, \\ Universidade do Porto, Rua do Campo Alegre, 687, P-4169-007 Porto, Portugal \\ ${ }^{2}$ Department of Chemical Engineering and Chemistry, Eindhoven University of Technology, Den Dolech 2, \\ 5612 AZ Eindhoven, The Netherlands \\ ${ }^{3}$ CICECO, Departamento de Química, Universidade de Aveiro, P-3810-193 Aveiro, Portugal
}

(Received 27 May 2014; accepted 17 September 2014; published online 3 October 2014)

\begin{abstract}
This work presents the vapor pressure at several temperatures for the 1,3-dialkylimidazolium bis(trifluoromethylsulfonyl)imide series, $\left[\mathrm{C}_{\mathrm{N} / 2} \mathrm{C}_{\mathrm{N} / 2} \mathrm{im}\right]\left[\mathrm{NTf}_{2}\right](\mathrm{N}=14,16,18$, and 20), measured by a Knudsen effusion method combined with a quartz crystal microbalance. The thermodynamic properties of vaporization of the ionic liquids under study are analysed together with the results obtained previously for the shorter alkyl chain length $\left[\mathrm{C}_{\mathrm{N} / 2} \mathrm{C}_{\mathrm{N} / 2} \mathrm{im}\right]\left[\mathrm{NTf}_{2}\right](\mathrm{N}=2,4,6,8,10$, and 12), in order to evaluate the effect of the alkyl side chains of the cation and to get additional insights concerning the nanostructuration of ionic liquids. The symmetry effect is explored, based on the comparison with the asymmetric imidazolium based ionic liquids, $\left[\mathrm{C}_{\mathrm{N}-1} \mathrm{C}_{1} \mathrm{im}\right]\left[\mathrm{NTf}_{2}\right]$. A trend shift on the thermodynamic properties of vaporization along the alkyl side chains of the extended symmetric ionic liquids, around $\left[\mathrm{C}_{6} \mathrm{C}_{6} \mathrm{im}\right]\left[\mathrm{NTf}_{2}\right]$, was detected. An intensification of the odd-even effect was observed starting from $\left[\mathrm{C}_{6} \mathrm{C}_{6} \mathrm{im}\right]\left[\mathrm{NTf}_{2}\right]$, with higher enthalpies and entropies of vaporization for the odd numbered ionic liquids, $\left[\mathrm{C}_{7} \mathrm{C}_{7} \mathrm{im}\right]\left[\mathrm{NTf}_{2}\right]$ and $\left[\mathrm{C}_{9} \mathrm{C}_{9} \mathrm{im}\right]\left[\mathrm{NTf}_{2}\right]$. Similar, but less pronounced, odd-even effect was found for the symmetric ionic liquids with lower alkyl side chains length, $\left[\mathrm{C}_{\mathrm{N} / 2} \mathrm{C}_{\mathrm{N} / 2} \mathrm{im}\right]\left[\mathrm{NTf}_{2}\right]$ (with $\mathrm{N}=4,6,8,10$, and 12). This effect is related with the predominant orientation of the terminal methyl group of the alkyl chain to the imidazolium ring and their influence in the cation-anion interaction. The same Critical Alkyl length at the hexyl, $\left(\mathrm{C}_{6} \mathrm{C}_{1}\right.$ and $\left.\mathrm{C}_{6} \mathrm{C}_{6}\right)$ was found for both asymmetric and symmetric series indicating that the nanostructuration of the ionic liquids is related with alkyl chain length. (C) 2014 AIP Publishing LLC. [http://dx.doi.org/10.1063/1.4896704]
\end{abstract}

\section{INTRODUCTION}

Until recently, the ionic liquids were regarded as non-volatile and believed to exhibit a non-measurable vapor pressure, even at high temperatures. Earle et al. ${ }^{1}$ has shown that some ionic liquids could be distillated at low pressure without decomposition. This study was followed by other works, where Kabo and collaborators ${ }^{2,3}$ reported the first experimental determinations of vapor pressures for a series of 1-alkyl-3-methylimidazolium bis(trifluoromethylsulfonyl)imide, $\left[\mathrm{C}_{\mathrm{N}-1} \mathrm{C}_{1}\right.$ im $]\left[\mathrm{NTf}_{2}\right](\mathrm{N}=3$, 5,7 , and 9; $\mathrm{N}$ represents the total number of carbons of the two alkyl chains of the cation), ionic liquids, using an integral effusion Knudsen method. In the same year, Santos et al. ${ }^{4}$ reported enthalpies of vaporization measured by a direct method (Calvet drop calorimeter) for seven $\left[\mathrm{C}_{\mathrm{N}-1} \mathrm{C}_{1} \mathrm{im}\right]\left[\mathrm{NTf}_{2}\right]$ ionic liquids. Accurate thermodynamic properties of vaporization of ionic liquids are scarce and yet crucial for the better understanding of the liquid phase of ionic liquids, evaluation of the cohesive energy, as well as the nature of the gaseous phase. Furthermore, they are required for validation and parameterization of the models (force fields) used to describe

\footnotetext{
a) Authors to whom correspondence should be addressed. Electronic addresses: 1bsantos@fc.up.pt and marisa.alexandra.rocha@gmail.com. Tel.: +351220402 836. Fax: +351220402659.
}

ionic liquids in different molecular simulation techniques. ${ }^{5-9}$ Despite the importance of the vapor pressures of the ionic liquids and the related thermodynamic properties of vaporization (enthalpies, entropies, and Gibbs energies of vaporization), most of the works performed until know were focused in estimate/determine the enthalpies of vaporization. ${ }^{7,10-21}$

The nature of the gas phase of ionic liquids is still in debate; however, the theory that the vaporization of ionic liquids occurs as a direct liquid to gas transfer of the intact ionic pair has been supported by several studies using photoionization, ${ }^{22}$ line of sight mass spectrometry, ${ }^{11,12,23}$ Fourier transform ion cyclotron resonance, ${ }^{24,25}$ field ionization method, ${ }^{26}$ tunable vacuum ultraviolet photoionization, ${ }^{15}$ and more recently by molecular dynamics simulations. ${ }^{27,28}$

Recently, we reported the thermodynamic study concerning the vaporization of the $\left[\mathrm{C}_{\mathrm{N}-1} \mathrm{C}_{1} \mathrm{im}\right]\left[\mathrm{NTf}_{2}\right](\mathrm{N}=3-9,11$, and 13) ionic liquid series, where important trends for the enthalpies and entropies of vaporization were found, which are related to a change in the molecular structure of the liquid phase around $\left[\mathrm{C}_{6} \mathrm{C}_{1} \mathrm{im}\right]\left[\mathrm{NTf}_{2}\right] .{ }^{29}$ Later on, the volatility study for the symmetric ionic liquids, $\left[\mathrm{C}_{\mathrm{N} / 2} \mathrm{C}_{\mathrm{N} / 2} \mathrm{im}\right]\left[\mathrm{NTf}_{2}\right]$ $(\mathrm{N}=4,6,8,10$, and 12), was reported and was found that the symmetry of the imidazolium cation leads to higher volatilities and lower enthalpies and entropies of vaporization, when compared with the asymmetric ILs, $\left[\mathrm{C}_{\mathrm{N}-1} \mathrm{C}_{1} \mathrm{im}\right]\left[\mathrm{NTf}_{2}\right] .{ }^{29}$ The effect of short alkyl chain length as well as the symmetry 
of the cation on the vaporization thermodynamics was evaluated based on the thermodynamic properties of vaporization of the $\left[\mathrm{C}_{1} \mathrm{C}_{1} \mathrm{im}\right]\left[\mathrm{NTf}_{2}\right]$ and $\left[\mathrm{C}_{2} \mathrm{C}_{3} \mathrm{im}\right]\left[\mathrm{NTf}_{2}\right] .{ }^{30}$ The previous studies are related with the effect of nanostructuration of ionic liquids on the thermodynamic properties of vaporization, that until recently it was mainly described by molecular simulation dynamics. 5,31,32 A discussion on the relation between the nature of the ions of the $\left[\mathrm{C}_{\mathrm{N}-1} \mathrm{C}_{1} \mathrm{im}\right]\left[\mathrm{NTf}_{2}\right]$ and their structure by molecular dynamics simulations was recently published by Shimizu et al. ${ }^{8}$ It was found that in small members of the ionic liquid series $\left(\left[\mathrm{C}_{2} \mathrm{C}_{1} \mathrm{im}\right]\left[\mathrm{NTf}_{2}\right]\right.$ $\left.\left[\mathrm{C}_{4} \mathrm{C}_{1} \mathrm{im}\right]\left[\mathrm{NTf}_{2}\right]\right)$ the alkyl side chains aggregates form elongated clusters with an increasing number of tails per aggregate which becomes more oblate around $\left[\mathrm{C}_{5} \mathrm{C}_{1} \mathrm{im}\right]\left[\mathrm{NTf}_{2}\right]$ and starting from $\left[\mathrm{C}_{6} \mathrm{C}_{1} \mathrm{im}\right]\left[\mathrm{NTf}_{2}\right]$ they form a second continuous sub-phase. This work was extended for the analysis of the nanostructuration behavior of the $\left[\mathrm{C}_{\mathrm{N} / 2} \mathrm{C}_{\mathrm{N} / 2} \mathrm{im}\right]\left[\mathrm{NTf}_{2}\right]$ ionic liquids using molecular dynamics simulations. 9 The analysis confirmed that the beginning of the nanostructuration/ alkyl chain segregation occurs when the total number of carbon atoms in the alkyl chain exceeds six. This findings support the previous interpretation of the experimental thermophysical results published on the literature. ${ }^{33,34}$ Despite the controversy around the so called trend shift on the enthalpies of vaporization, ${ }^{35}$ the effect nanostructuration in ionic liquids was already detected in several other properties. $^{33,34,36-42}$

This work presents vapor pressure data for the 1,3dialkylimidazolium bis(trifluoromethylsulfonyl)imide series, $\left[\mathrm{C}_{\mathrm{N} / 2} \mathrm{C}_{\mathrm{N} / 2} \mathrm{im}\right]\left[\mathrm{NTf}_{2}\right](\mathrm{N}=14,16,18$, and 20$)$, with long alkyl side chains. This is an extension of the thermodynamic study of vaporization for the $\left[\mathrm{C}_{\mathrm{N} / 2} \mathrm{C}_{\mathrm{N} / 2} \mathrm{im}\right]\left[\mathrm{NTf}_{2}\right](\mathrm{N}=2,4,6,8$, 10 , and 12), reported recently in the literature. ${ }^{30,43}$ The analysis and rationalization of the obtained results will be done considering the thermodynamic properties of vaporization of the symmetric ionic liquids with shorter alkyl side chains, $\left[\mathrm{C}_{\mathrm{N} / 2} \mathrm{C}_{\mathrm{N} / 2} \mathrm{im}\right]\left[\mathrm{NTf}_{2}\right](\mathrm{N}=2,4,6,8,10$, and 12$),{ }^{30,43}$ in order to evaluate the effect of the alkyl side chains of the cation and to get more insights about the nanostructuration of ionic liquids. ${ }^{5,31}$ The symmetry effect of the long alkyl side chain cations, $\left[\mathrm{C}_{\mathrm{N} / 2} \mathrm{C}_{\mathrm{N} / 2} \mathrm{im}\right]\left[\mathrm{NTf}_{2}\right](\mathrm{N}=14,16,18$, and 20), presented in this work, will be investigated based on the comparison with the asymmetric imidazolium based ionic liquids, $\left[\mathrm{C}_{\mathrm{N}-1} \mathrm{C}_{1} \mathrm{im}\right]\left[\mathrm{NTf}_{2}\right] .{ }^{29}$

\section{EXPERIMENTAL DETAILS}

The 1,3-dialkylimidazolium bis(trifluoromethylsulfonyl) imide series, $\left[\mathrm{C}_{\mathrm{N} / 2} \mathrm{C}_{\mathrm{N} / 2} \mathrm{im}\right]\left[\mathrm{NTf}_{2}\right](\mathrm{N}=14,16,18$, and 20), used in this work, were purchased from IOLITEC with a stated purity of better than $98 \%$. The purity of each ionic liquid was further evaluated by ${ }^{1} \mathrm{H},{ }^{13} \mathrm{C}$, and ${ }^{19} \mathrm{~F}$ NMR spectra were recorded on a Bruker Avance $300\left[300.13 \mathrm{MHz}\left({ }^{1} \mathrm{H}\right)\right.$, $282.41 \mathrm{MHz}\left({ }^{19} \mathrm{~F}\right)$, and $\left.75.47 \mathrm{MHz}\left({ }^{13} \mathrm{C}\right)\right]$ spectrometer, and the solvent used was DMSO D6. The ionic liquids were found to be $>99$ wt. $\%$ purity. The halide content was assumed to be the one presented on the certificate of analysis, 2000$3000 \mathrm{ppm}$. The NMR spectra for each ionic liquid are presented in the supplementary material. ${ }^{65}$ In order to reduce the presence of water or other volatile contents, the ionic liquids samples were dried under reduced pressure $(<10 \mathrm{~Pa})$ and constantly stirred at $323 \mathrm{~K}$, during $48 \mathrm{~h}$ and kept under vacuum. The ionic liquids were additionally degassed in situ in the Knudsen chamber at high vacuum $\left(p<10^{-5} \mathrm{~Pa}\right)$ at $400 \mathrm{~K}$ during $4 \mathrm{~h}$ prior the vapor pressure measurements.

\section{A. Quartz crystal microbalance Knudsen effusion apparatus}

The vapor pressures of the studied ionic liquids were measured as a function of the temperature using Knudsen effusion apparatus combined with a quartz crystal microbalance, KEQCM, described in detail in the literature. ${ }^{44}$ Basically, this apparatus results on the combination of the Knudsen effusion (KE) technique and quartz crystal microbalance (QCM). The combination of two mass loss detection techniques (gravimetric and quartz crystal microbalance) presents several advantages: small effusion times; smaller sample sizes; higher control of the vaporization process, since it is possible to detect some problem during the experiment by the monitoring the change of the crystal's resonant frequency with time. Additionally, the instrument enables the measurement of vapor pressures from $0.005 \mathrm{~Pa}$ up to $1 \mathrm{~Pa}$. The temperature is controlled within a temperature fluctuation of $\pm\left(1 \times 10^{-2}\right) \mathrm{K}$, measured with a resolution better than $1 \times 10^{-3} \mathrm{~K}$ and along the working temperature range, the overall uncertainty is better than $\pm\left(2 \times 10^{-2}\right) \mathrm{K}$. The vapor pressure data obtained with this apparatus for the ionic liquid have a typical pressure dependent uncertainty of (1\%-5\%). ${ }^{29}$ The relative atomic masses used were those recommended by the IUPAC Commission in 2007. ${ }^{45}$

The procedure for measuring the vapor pressures of ionic liquids using the Knudsen effusion includes an additional step of in situ purification until the vapor pressure remains constant. This procedure is performed with the ionic liquid inside the effusion cell, at $470 \mathrm{~K}$ under high vacuum $(<0.001 \mathrm{~Pa})$. The purity control of the ionic liquid inside the effusion cell and the condensed on the quartz crystal microbalance along the effusion experiments was followed by RMN, no detectable change between the initial spectra and the samples were observed. However, a small change in the intensity of the initial slight yellowish colour of some samples was observed on the effusion cell. The distillate (condensate sample in the quartz crystal) was always found to be clear. The sample was changed by a fresh and dry sample, for new independent experiments when the yellowish colour intensification of the ionic liquids was observed (typically after keeping the effusion cell for long periods at high temperatures $\sim 48 \mathrm{~h}$ ). It was found no correlation in the vapor pressure obtained results and the level of the yellowish colour indicating that the decomposition products should be very little volatile and their effect in the IL volatility is undetectable in our apparatus. We found that there is a significant increase in the quality and purity of the distilled. The analysis of the ILs recovered at the quartz crystal surface show a quite significant increase in purity. The fluids are colorless and present high quality NMR spectra. 
TABLE I. Experimental vapor pressures for the studied imidazolium based ILs, as obtained with the quartz crystal microbalance Knudsen effusion apparatus. ${ }^{\text {a }}$

\begin{tabular}{|c|c|c|c|c|c|c|c|c|}
\hline$T(\mathrm{~K})$ & $p(\mathrm{~Pa})$ & $\Delta p(\mathrm{~Pa})$ & $T(\mathrm{~K})$ & $p(\mathrm{~Pa})$ & $\Delta p(\mathrm{~Pa})$ & $T(\mathrm{~K})$ & $p(\mathrm{~Pa})$ & $\Delta p(\mathrm{~Pa})$ \\
\hline \multicolumn{9}{|c|}{$\left[\mathrm{C}_{7} \mathrm{C}_{7} \mathrm{im}\right]\left[\mathrm{NTf}_{2}\right]$} \\
\hline 483.37 & 0.0540 & -0.0101 & 491.17 & 0.0896 & 0.0046 & 499.29 & 0.1517 & -0.0021 \\
\hline 485.37 & 0.0613 & -0.0013 & 493.17 & 0.1020 & 0.0052 & 501.41 & 0.1738 & -0.0063 \\
\hline 487.38 & 0.0698 & 0.0041 & 495.28 & 0.1176 & -0.0016 & 503.41 & 0.1948 & 0.0033 \\
\hline 489.27 & 0.0789 & 0.0069 & 497.28 & 0.1338 & -0.0031 & & & \\
\hline \multicolumn{9}{|c|}{$\left[\mathrm{C}_{8} \mathrm{C}_{8} \mathrm{im}\right]\left[\mathrm{NTf}_{2}\right]$} \\
\hline 483.29 & 0.0368 & 0.0104 & 493.33 & 0.0712 & -0.0056 & 503.36 & 0.1301 & 0.0005 \\
\hline 485.31 & 0.0423 & 0.0036 & 495.34 & 0.0801 & 0.0013 & 505.37 & 0.1462 & 0.0019 \\
\hline 487.32 & 0.0486 & -0.0050 & 497.34 & 0.0902 & 0.0053 & & & \\
\hline 489.33 & 0.0554 & -0.0070 & 499.35 & 0.1019 & 0.0054 & & & \\
\hline 491.32 & 0.0629 & -0.0078 & 501.36 & 0.1159 & -0.0028 & & & \\
\hline \multicolumn{9}{|c|}{$\left[\mathrm{C}_{9} \mathrm{C}_{9} \mathrm{im}\right]\left[\mathrm{NTf}_{2}\right]$} \\
\hline 493.11 & 0.0448 & -0.0034 & 508.11 & 0.1115 & 0.0216 & 523.09 & 0.2765 & -0.0242 \\
\hline 498.13 & 0.0626 & -0.0158 & 513.11 & 0.1510 & 0.0140 & & & \\
\hline 503.16 & 0.0843 & 0.0006 & 518.11 & 0.2027 & 0.0073 & & & \\
\hline \multicolumn{9}{|c|}{$\left[\mathrm{C}_{10} \mathrm{C}_{10} \mathrm{im}\right]\left[\mathrm{NTf}_{2}\right]$} \\
\hline 491.35 & 0.0251 & 0.0056 & 499.36 & 0.0416 & -0.0021 & 507.37 & 0.0669 & -0.0009 \\
\hline 493.34 & 0.0287 & -0.0029 & 501.35 & 0.0466 & 0.0051 & 509.38 & 0.0750 & 0.0007 \\
\hline 495.34 & 0.0326 & -0.0051 & 503.36 & 0.0528 & -0.0003 & 511.38 & 0.0843 & -0.0016 \\
\hline 497.35 & 0.0368 & -0.0023 & 505.36 & 0.0594 & 0.0005 & 513.38 & 0.0941 & 0.0015 \\
\hline
\end{tabular}

a $\Delta p=p-p_{\text {calc }}$, where $p_{\text {calc }}$ is calculated from the Clarke and Glew equation (Eq. (2)) with the parameters given in Table II. Standard uncertainties, $u$, are $u(T)=0.02 \mathrm{~K}, u(p)=$ $(0.001+0.05 \cdot p) \mathrm{Pa}$, the 0.95 confidence level $(\mathrm{k} \approx 2)$.

\section{RESULTS AND DISCUSSION}

The vapor pressures were measured at different temperatures intervals, $\left[\mathrm{C}_{7} \mathrm{C}_{7} \mathrm{im}\right]\left[\mathrm{NTf}_{2}\right] \quad(483-504) \mathrm{K}$, $\left[\mathrm{C}_{8} \mathrm{C}_{8} \mathrm{im}\right]\left[\mathrm{NTf}_{2}\right](483-506) \mathrm{K},\left[\mathrm{C}_{9} \mathrm{C}_{9} \mathrm{im}\right]\left[\mathrm{NTf}_{2}\right](493-523) \mathrm{K}$, and $\left[\mathrm{C}_{10} \mathrm{C}_{10} \mathrm{im}\right]\left[\mathrm{NTf}_{2}\right](491-514) \mathrm{K}$, using a Knudsen effusion apparatus combined with a quartz crystal microbalance. The experimental vapor pressures data for each studied ionic liquid are presented in Table I. Figure 1 presents the graphical

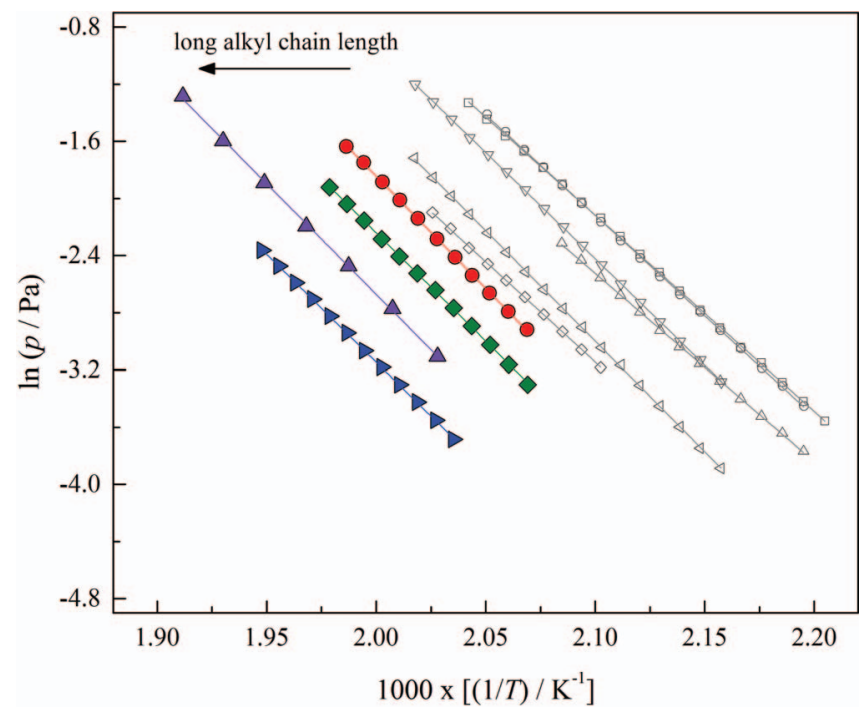

FIG. 1. Plot of $\ln (p / \mathrm{Pa})=\mathrm{f}\left[(1 / T) / \mathrm{K}^{-1}\right]$ for the studied ionic liquid: - (red) - $\left[\mathrm{C}_{7} \mathrm{C}_{7} \mathrm{im}\right]\left[\mathrm{NTf}_{2}\right]$; $\bullet$ (green) $-\left[\mathrm{C}_{8} \mathrm{C}_{8} \mathrm{im}\right]\left[\mathrm{NTf}_{2}\right]$; $\Delta$ (violet) $-\left[\mathrm{C}_{9} \mathrm{C}_{9} \mathrm{im}\right]\left[\mathrm{NTf}_{2}\right]$; and (blue) $-\left[\mathrm{C}_{10} \mathrm{C}_{10} \mathrm{im}^{-}\left[\mathrm{NTf}_{2}\right]\right.$. Rocha et al.:43 $\diamond$ (gray) $-\left[\mathrm{C}_{1} \mathrm{C}_{1} \mathrm{im}\right]\left[\mathrm{NTf}_{2}\right] ; \Delta$ (gray) $-\left[\mathrm{C}_{2} \mathrm{C}_{2} \mathrm{im}\right]\left[\mathrm{NTf}_{2}\right] ; \square$ (gray) - $\left[\mathrm{C}_{3} \mathrm{C}_{3} \mathrm{im}\right]\left[\mathrm{NTf}_{2}\right] ; \bigcirc$ (gray) $-\left[\mathrm{C}_{4} \mathrm{C}_{4} \mathrm{im}_{2}\right]\left[\mathrm{NTf}_{2}\right] ; \quad \nabla$ (gray) $\left[\mathrm{C}_{5} \mathrm{C}_{5} \mathrm{im}\right]\left[\mathrm{NTf}_{2}\right]$; and $\triangleleft$ (gray) $-\left[\mathrm{C}_{6} \mathrm{C}_{6}\right.$ im $]\left[\mathrm{NTf}_{2}\right]$. representation of $\ln (p / \mathrm{Pa})=\mathrm{f}\left[(1 / T) / \mathrm{K}^{-1}\right]$ for the studied compounds.

The experimental (pressure - temperature) results were fitted to the integrated form of the Clausius-Clapeyron, Eq. (1).

$$
\ln (p / \mathrm{Pa})=a+b / T(K),
$$

where $p$ is the pressure in $\mathrm{Pa}$ and $T$ is the temperature in $\mathrm{K}, a$ and $b$ are the fitted parameters, listed in Table II.

The thermodynamic properties of vaporization at the mean temperature, $\langle T\rangle$, and reference temperatures, $\theta, 460 \mathrm{~K}$ and $298.15 \mathrm{~K}$, were derived from the fitting of the experimental results of the vapor pressures by the truncated form of the Clarke and Glew equation, ${ }^{46}$ Eq. (2):

$$
\begin{aligned}
R \cdot \ln \frac{p}{p^{\mathrm{o}}}= & -\frac{\Delta_{1}^{\mathrm{g}} G_{\mathrm{m}}^{\mathrm{o}}(\theta)}{\theta}+\Delta_{\mathrm{l}}^{\mathrm{g}} H_{\mathrm{m}}^{\mathrm{o}}(\theta) \cdot\left(\frac{1}{\theta}-\frac{1}{T}\right) \\
& +\Delta_{1}^{\mathrm{g}} C_{p, \mathrm{~m}}^{\mathrm{o}} \cdot\left[\frac{\theta}{T}-1+\ln \left(\frac{T}{\theta}\right)\right],
\end{aligned}
$$

where $p$ is the vapor pressure, $p^{\circ}$ is the standard pressure ( $p^{\mathrm{o}}=10^{5} \mathrm{~Pa}$ ), $\theta$ is a selected reference temperature, $R$ is the gas constant $\left(R=8.3144621 \mathrm{~J} \mathrm{~K}^{-1} \mathrm{~mol}^{-1}\right),{ }^{47} \Delta_{1}^{\mathrm{g}} G_{\mathrm{m}}^{\mathrm{o}}$ is the

TABLE II. Fitted $a$ and $b$ parameters, of the integrated Clausius-Clapeyron equation for the studied ionic liquids.

\begin{tabular}{lccc}
\hline \hline Ionic liquid & $a \pm \sigma$ & $(b \pm \sigma)(\mathrm{K})$ & $r^{2}$ \\
\hline$\left[\mathrm{C}_{7} \mathrm{C}_{7} \mathrm{im}\right]\left[\mathrm{NTf}_{2}\right]$ & $28.09 \pm 0.15$ & $-15165 \pm 74$ & 0.9998 \\
{$\left[\mathrm{C}_{8} \mathrm{C}_{8} \mathrm{im}\right]\left[\mathrm{NTf}_{2}\right]$} & $29.63 \pm 0.11$ & $-15736 \pm 57$ & 0.9999 \\
{$\left[\mathrm{C}_{9} \mathrm{C}_{9} \mathrm{im}\right]\left[\mathrm{NTf}_{2}\right]$} & $28.29 \pm 0.28$ & $-15480 \pm 143$ & 0.9996 \\
{$\left[\mathrm{C}_{10} \mathrm{C}_{10} \mathrm{im}\right]\left[\mathrm{NTf}_{2}\right]$} & $27.01 \pm 0.09$ & $-15078 \pm 44$ & 0.9999 \\
\hline \hline
\end{tabular}


TABLE III. Parameters of Clarke and Glew equation fitted from the vapor pressure results and the derived standard $\left(p^{\circ}=10^{5}\right.$ Pa) molar entropy of vaporization for each studied IL at the temperature, $\theta$.

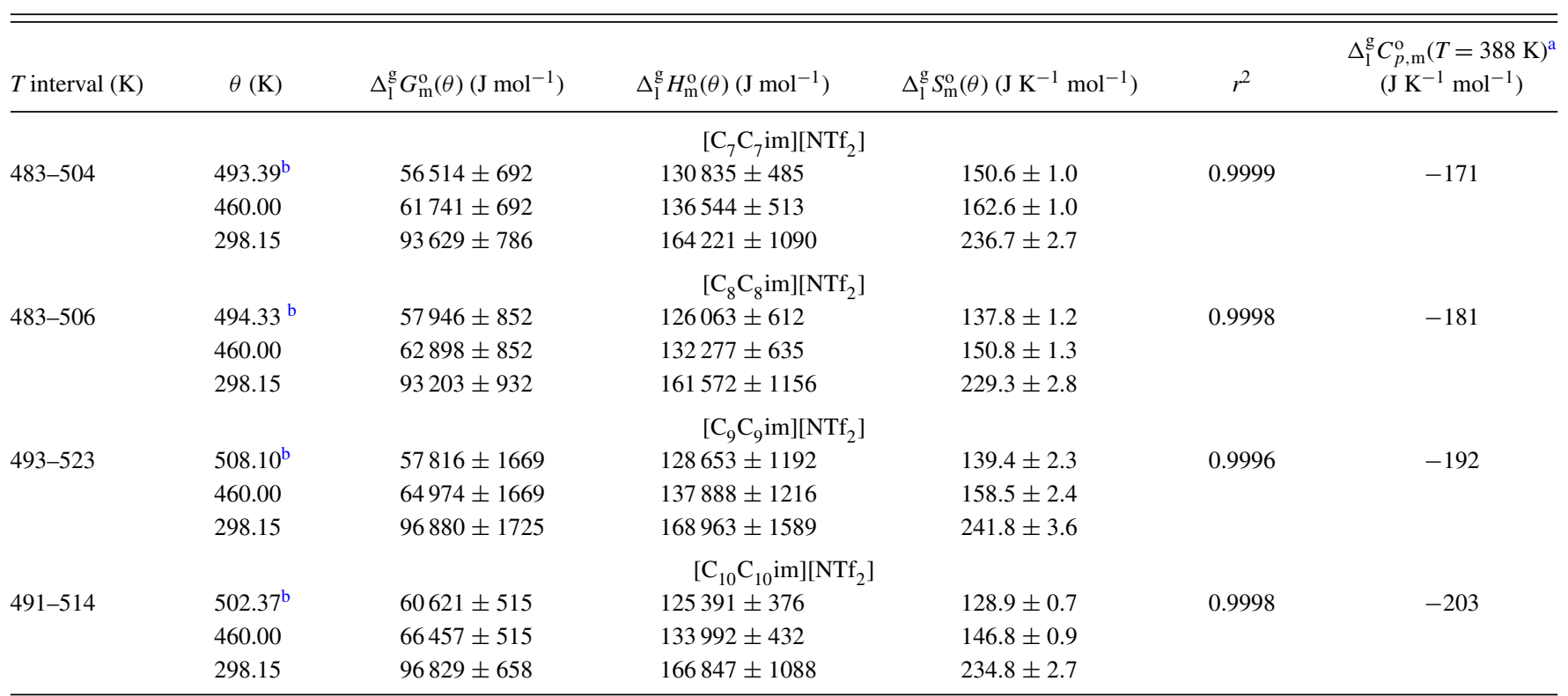

${ }^{\mathrm{a}} \Delta_{1}^{\mathrm{g}} C_{p, \mathrm{~m}}^{\mathrm{o}}(T=388 \mathrm{~K})$ estimated using the linear fitted function $\left[\Delta_{1}^{\mathrm{g}} C_{p, \mathrm{~m}}^{\mathrm{o}}(T=388 \mathrm{~K})=-5.40 n(\mathrm{C})-100.47\right]$ derived from fitting of the literature data of $\Delta_{1}^{\mathrm{g}} C_{p, \mathrm{~m}}^{\mathrm{o}}(T=388 \mathrm{~K})$ as a

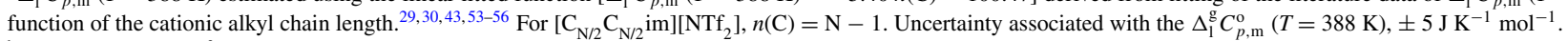

${ }^{\mathrm{b}}$ Mean temperature. $r^{2}$ is the linear regression coefficient.

standard molar Gibbs energy of vaporization at the selected reference pressure, $\Delta_{1}^{\mathrm{g}} H_{\mathrm{m}}^{\mathrm{o}}$ is the standard molar enthalpy of vaporization, and $\Delta_{l}^{\mathrm{g}} C_{p, \mathrm{~m}}^{\mathrm{o}}$ is the difference between the heat capacities of the gaseous and of the liquid phases $\left[\Delta_{1}^{\mathrm{g}} C_{p, \mathrm{~m}}^{\mathrm{o}}\right.$ $\left.=C_{p, \mathrm{~m}}^{\mathrm{o}}(\mathrm{g})-C_{p, \mathrm{~m}}^{\mathrm{o}}(\mathrm{l})\right]$. The values of $\Delta_{1}^{\mathrm{g}} C_{p, \mathrm{~m}}^{\mathrm{o}}$ imposed in Eq. (2) are presented in Table III.

The thermodynamic properties of vaporization derived from Eq. (2) at the mean temperature, $\langle T\rangle$, and references temperatures, $\theta, 460 \mathrm{~K}$, and $298.15 \mathrm{~K}$, together with the used $\Delta_{1}^{\mathrm{g}} C_{p, \mathrm{~m}}^{\mathrm{o}}$, are presented in Table III.

The effect of the $\Delta_{1}^{\mathrm{g}} C_{p, \mathrm{~m}}^{\mathrm{o}}$ on the enthalpies of vaporization of $\left[\mathrm{C}_{\mathrm{N}-1} \mathrm{C}_{1} \mathrm{im}\right]\left[\mathrm{NTf}_{2}\right]$ has been assessed recently by Verevkin et al. ${ }^{13,18,35,48-50}$ Until recently, temperature correction of the literature values for enthalpies of vaporization have been done using two values of $\Delta_{1}^{\mathrm{g}} C_{p, \mathrm{~m}}^{\mathrm{o}},\left(-100 \mathrm{~J} \mathrm{~K}^{-1}\right.$ $\left.\mathrm{mol}^{-1}\right)^{3,49-52}$ and $\left(-40 \mathrm{~J} \mathrm{~K}^{-1} \mathrm{~mol}^{-1}\right)^{18,35}$ and only recently it was considered the temperature and chain length of the cation dependence of $\Delta_{1}^{\mathrm{g}} C_{p, \mathrm{~m}}^{\mathrm{o}} \cdot{ }^{35}$

In our previous works, ${ }^{29,30,43}$ the values of $\Delta_{1}^{\mathrm{g}} C_{p, \mathrm{~m}}^{\mathrm{o}}$ were estimated for the same temperature, $T=388 \mathrm{~K}$, based on the linear correlation of the literature values ${ }^{53-56}$ for $C_{p, \mathrm{~m}}^{\mathrm{o}}(\mathrm{l})$ and $C_{p, \mathrm{~m}}^{\mathrm{o}}(\mathrm{g})$ as a function of the cation's alkyl chain length, using the previously described methodology. ${ }^{29,30,43}$ In order to keep consistency with our previous works, ${ }^{29,30,43}$ in the present work we use the same methodology. The most recent data of $\Delta_{1}^{\mathrm{g}} C_{p, \mathrm{~m}}^{\mathrm{o}}$ suggested by Verevkin et al. of $-40 \mathrm{~J}$ $\mathrm{K}^{-1} \mathrm{~mol}^{-118,35}$ is not supported by the typical experimental difference between the heat capacities of the liquid and solid phases in ionic liquids, $\Delta_{\mathrm{cr}}^{1} C_{p, \mathrm{~m}}^{\mathrm{o}}\left(+50\right.$ to $\left.+100 \mathrm{~J} \mathrm{~K}^{-1} \mathrm{~mol}^{-1}\right)$ which leads to an unexpected and not coherent, high and positive difference between the heat capacities of the liquid and gas phases. ${ }^{54,57-60}$ A recent Monte Carlo simulation study by Rane et al. ${ }^{61}$ provided additional support for our correlation concerning the $\Delta_{1}^{\mathrm{g}} C_{p, \mathrm{~m}}^{\mathrm{o}}$.
This is the first work addressing the volatility study of $\left[\mathrm{C}_{\mathrm{N} / 2} \mathrm{C}_{\mathrm{N} / 2} \mathrm{im}\right]\left[\mathrm{NTf}_{2}\right](\mathrm{N}=14,16,18$, and 20$)$ ionic liquid series with long alkyl chain length. The analysis and rationalization of the present results will be done considering the thermodynamic properties of vaporization of the symmetric ionic liquids with shorter alkyl side chains recently published in the literature, $\left[\mathrm{C}_{\mathrm{N} / 2} \mathrm{C}_{\mathrm{N} / 2} \mathrm{im}\right]\left[\mathrm{NTf}_{2}\right](\mathrm{N}=2,4,6,8,10 \text {, and } 12)^{30,43}$ in order to evaluate the dependency of the alkyl side chain and the symmetry effect on the properties will be investigated based on the comparison with the asymmetric imidazolium based ionic liquids, $\left[\mathrm{C}_{\mathrm{N}-1} \mathrm{C}_{1}\right.$ im $]\left[\mathrm{NTf}_{2}\right] .{ }^{29}$

The trends detected on the thermodynamic properties of vaporization of $\left[\mathrm{C}_{\mathrm{N}-1} \mathrm{C}_{1} \mathrm{im}\right]\left[\mathrm{NTf}_{2}\right]$ which presents an experimental evidence of the so-called nanostructuration/segregation of ionic liquids has been intensively discussed. ${ }^{35}$ Despite of the efforts to clarify the existing discrepancy on the enthalpies of vaporization values published in the literature, the question remains yet to be solved. Nevertheless, the effect of nanostructuration/segregation of ionic liquids on the static and dynamic properties of these compounds has been established in previous works. ${ }^{33,34,36-42} \mathrm{~A}$ critical analysis of the enthalpies of vaporization for the $\left[\mathrm{C}_{\mathrm{N}-1} \mathrm{C}_{1} \mathrm{im}\right]\left[\mathrm{NTf}_{2}\right]$ ionic liquid series and the dependency of the data with the chain length of the alkyl group of the cation has been recently published. ${ }^{35}$ Therefore, and considering the fact that literature data for this new ionic liquids are not available, in this work the discussion will be made focusing on the data obtained based on experimental vapor pressures.

The plots of $\ln (p / \mathrm{Pa})$ as a function of $\left[(1 / T) / \mathrm{K}^{-1}\right]$ presented in Figure 1, show that, in the measured temperature range, the volatility of the $\left[\mathrm{C}_{\mathrm{N} / 2} \mathrm{C}_{\mathrm{N} / 2} \mathrm{im}\right]\left[\mathrm{NTf}_{2}\right]$ ionic liquids decreases along the homologous series, from $\left[\mathrm{C}_{3} \mathrm{C}_{3} \mathrm{im}\right]\left[\mathrm{NTf}_{2}\right]$ to $\left[\mathrm{C}_{10} \mathrm{C}_{10} \mathrm{im}\right]\left[\mathrm{NTf}_{2}\right]$, where $\left[\mathrm{C}_{3} \mathrm{C}_{3} \mathrm{im}\right]\left[\mathrm{NTf}_{2}\right]$ presents a similar volatility than the $\left[\mathrm{C}_{4} \mathrm{C}_{4} \mathrm{im}\right]\left[\mathrm{NTf}_{2}\right]$ and $\left[\mathrm{C}_{10} \mathrm{C}_{10} \mathrm{im}\right]\left[\mathrm{NTf}_{2}\right]$ 

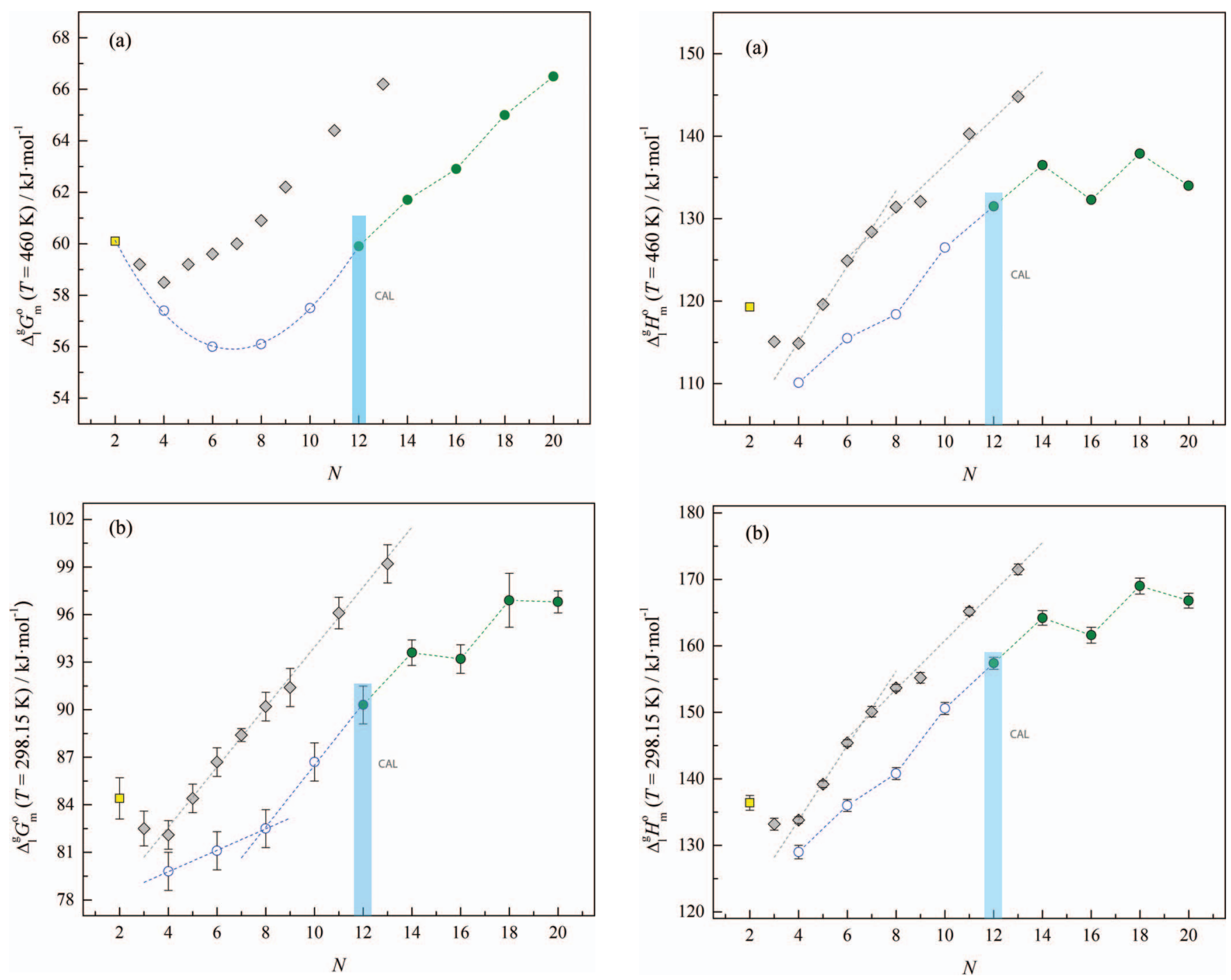

FIG. 2. Standard $\left(p^{\mathrm{o}}=10^{5} \mathrm{~Pa}\right)$ molar Gibbs energy of vaporization as a function of the total number of carbons in the alkyl side chains of the cation, $N$. (a) $\Delta_{1}^{\mathrm{g}} G_{\mathrm{m}}^{\mathrm{o}}(T=460 \mathrm{~K})$ and (b) $\Delta_{\mathrm{l}}^{\mathrm{g}} G_{\mathrm{m}}^{\mathrm{o}}(T=298.15 \mathrm{~K})$. Literature: (yellow) $-\left[\mathrm{C}_{1} \mathrm{C}_{1}\right.$ im $]\left[\mathrm{NTf}_{2}\right] ;^{30} \rightarrow$ (gray) $-\left[\mathrm{C}_{\mathrm{N}-1} \mathrm{C}_{1}\right.$ im $]\left[\mathrm{NTf}_{2}\right](\mathrm{N}=3-9,11$, and 13); ${ }^{29}$ and $\bigcirc$ (blue) $-\left[\mathrm{C}_{\mathrm{N} / 2} \mathrm{C}_{\mathrm{N} / 2}\right.$ im] $\left[\mathrm{NTf}_{2}\right]\left(\mathrm{N}=4,6,8,10\right.$, and 12). ${ }^{43}$ This work: (green) $-\left[\mathrm{C}_{\mathrm{N} / 2} \mathrm{C}_{\mathrm{N} / 2}\right.$ im] $\left.] \mathrm{NTf}_{2}\right](\mathrm{N}=14,16,18$, and 20). Critical Alkyl Length (CAL), $\left[\mathrm{C}_{6} \mathrm{C}_{6}\right.$ im] $\left[\mathrm{NTf}_{2}\right]$.

is the less volatile ionic liquid in the studied series. As previously observed, $\left[\mathrm{C}_{1} \mathrm{C}_{1}\right.$ im $]\left[\mathrm{NTf}_{2}\right]$ and $\left[\mathrm{C}_{2} \mathrm{C}_{2} \mathrm{im}\right]\left[\mathrm{NTf}_{2}\right]$ present an outlier behaviour, with lower volatilities than $\left[\mathrm{C}_{3} \mathrm{C}_{3} \mathrm{im}\right]\left[\mathrm{NTf}_{2}\right]$ and $\left[\mathrm{C}_{4} \mathrm{C}_{4}\right.$ im $]\left[\mathrm{NTf}_{2}\right] .30,43$

The graphic representations of the standard molar enthalpies, entropies, and Gibbs energies of vaporization at reference temperatures ( $460 \mathrm{~K}$ and $298.15 \mathrm{~K}$ ) as a function of the total number of carbon atoms in the two alkyl side chains of the cation, $N$, are presented in Figures 2-4. The thermodynamic properties of vaporization of $\left[\mathrm{C}_{\mathrm{N} / 2} \mathrm{C}_{\mathrm{N} / 2} \mathrm{im}\right]$ [NTf ${ }_{2}$ (with $\mathrm{N}=14,16,18$, and 20), are compared with $\left[\mathrm{C}_{\mathrm{N} / 2} \mathrm{C}_{\mathrm{N} / 2} \mathrm{im}\right]\left[\mathrm{NTf}_{2}\right]$ (with $\mathrm{N}=2,4,6,8,10$, and 12), ${ }^{30,43}$ and with $\left[\mathrm{C}_{\mathrm{N}-1} \mathrm{C}_{1} \mathrm{im}\right]\left[\mathrm{NTf}_{2}\right]$ (with $\mathrm{N}=3-9,11$, and 13). ${ }^{38}$ The data at reference temperature, $T=460 \mathrm{~K}$, are reported to prove that the $\Delta_{1}^{\mathrm{g}} C_{p, \mathrm{~m}}^{\mathrm{o}}$ adopted does not affect the trends with the alkyl chain length observed on the thermodynamic properties of vaporization at $298.15 \mathrm{~K}$.

FIG. 3. Standard $\left(p^{\circ}=10^{5} \mathrm{~Pa}\right)$ molar enthalpy of vaporization as a function of the total number of carbons in the alkyl side chains of the cation, $N$. (a) $\Delta_{\mathrm{l}}^{\mathrm{g}} H_{\mathrm{m}}^{\mathrm{o}}(T=460 \mathrm{~K})$ and (b) $\Delta_{\mathrm{l}}^{\mathrm{g}} H_{\mathrm{m}}^{\mathrm{o}}(T=298.15 \mathrm{~K})$. Literature: $\mathbf{\square}$ (yellow) $-\left[\mathrm{C}_{1} \mathrm{C}_{1}\right.$ im $]\left[\mathrm{NTf}_{2}\right] ; 30$ (gray) $-\left[\mathrm{C}_{\mathrm{N}-1} \mathrm{C}_{1}\right.$ im $^{30}\left[\mathrm{NTf}_{2}\right](\mathrm{N}=3-9,11$, and 13); ${ }^{29}$ and $\bigcirc$ (blue) $-\left[\mathrm{C}_{\mathrm{N} / 2} \mathrm{C}_{\mathrm{N} / 2} \mathrm{im}\right]\left[\mathrm{NTf}_{2}\right]\left(\mathrm{N}=4,6,8,10\right.$, and 12). ${ }^{43}$ This work: (green) $-\left[\mathrm{C}_{\mathrm{N} / 2} \mathrm{C}_{\mathrm{N} / 2} \mathrm{im}\right]\left[\mathrm{NTf}_{2}\right](\mathrm{N}=14,16,18$, and 20).Critical Alkyl Length (CAL), $\left[\mathrm{C}_{6} \mathrm{C}_{6}\right.$ im] $\left[\mathrm{NTf}_{2}\right]$.

If we consider the linear trend of standard molar Gibbs energies of vaporization, at $T=298.15 \mathrm{~K}$, of the asymmetric ionic liquids $\left(\left[\mathrm{C}_{\mathrm{N}-1} \mathrm{C}_{1} \mathrm{im}\right]\left[\mathrm{NTf}_{2}\right]\right),{ }^{29}$ the volatility of the symmetric ionic liquids with longer alkyl side chains is significantly higher than the asymmetric ILs. Instead of a gradual linear increase of the $\Delta_{1}^{\mathrm{g}} G_{\mathrm{m}}^{\mathrm{o}}$ (decrease of the volatility) along the alkyl side chain length of the asymmetric ionic liquids, ${ }^{29}$ the symmetric ionic liquid series with longer alkyl side chain length presents the following order of volatility, at $T=298.15 \mathrm{~K}$ :

$$
\begin{aligned}
{\left[\mathrm{C}_{2} \mathrm{C}_{2} \mathrm{im}\right]\left[\mathrm{NTf}_{2}\right]>\left[\mathrm{C}_{3} \mathrm{C}_{3} \mathrm{im}\right]\left[\mathrm{NTf}_{2}\right]>\left[\mathrm{C}_{4} \mathrm{C}_{4} \mathrm{im}\right]\left[\mathrm{NTf}_{2}\right] } \\
\gg\left[\mathrm{C}_{5} \mathrm{C}_{5} \mathrm{im}_{[}\right]\left[\mathrm{NTf}_{2}\right] \gg\left[\mathrm{C}_{6} \mathrm{C}_{6} \mathrm{im}\right]\left[\mathrm{NTf}_{2}\right] \\
\gg\left[\mathbf{C}_{\mathbf{7}} \mathbf{C}_{\mathbf{7}} \mathbf{i m}\right]\left[\mathbf{N T f}_{\mathbf{2}}\right] \approx\left[\mathbf{C}_{\mathbf{8}} \mathbf{C}_{\mathbf{8}} \mathbf{i m}\right]\left[\mathbf{N T f}_{\mathbf{2}}\right] \\
\gg\left[\mathbf{C}_{\mathbf{9}} \mathbf{C}_{\mathbf{9}} \mathbf{i m}\right]\left[\mathbf{N T f}_{\mathbf{2}}\right] \approx\left[\mathbf{C}_{\mathbf{1 0}} \mathbf{C}_{\mathbf{1 0}} \mathbf{i m}\right]\left[\mathbf{N T f}_{\mathbf{2}}\right] .
\end{aligned}
$$



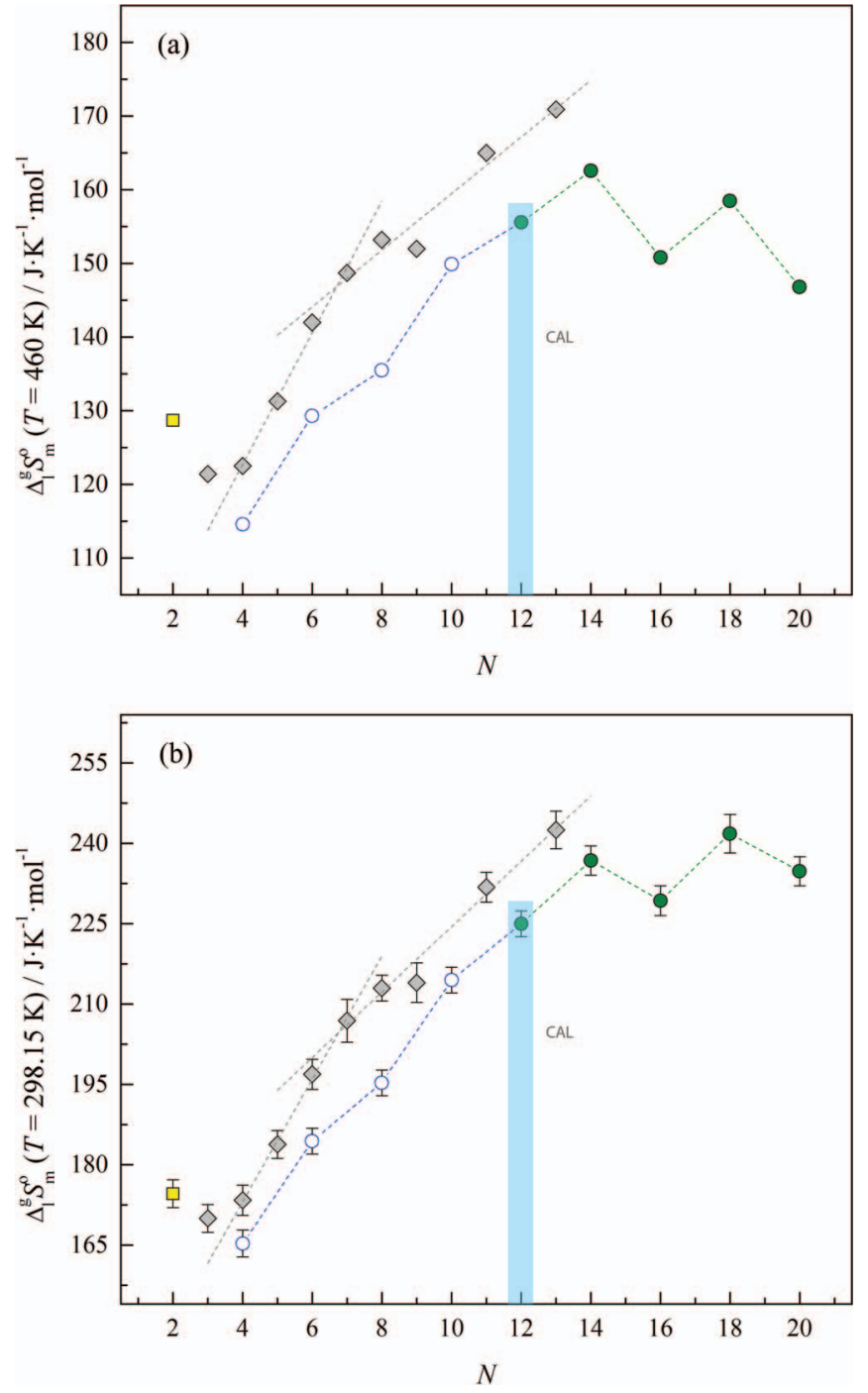

FIG. 4. Standard $\left(p^{0}=10^{5} \mathrm{~Pa}\right)$ molar entropy of vaporization as a function of the total number of carbons in the alkyl side chains of the cation, $N$. (a) $\Delta_{\mathrm{l}}^{\mathrm{g}} S_{\mathrm{m}}^{\mathrm{o}}(T=460 \mathrm{~K})$ and (b) $\Delta_{\mathrm{l}}^{\mathrm{g}} S_{\mathrm{m}}^{\mathrm{o}}(T=298.15 \mathrm{~K})$. Literature: (yellow) $-\left[\mathrm{C}_{1} \mathrm{C}_{1}\right.$ im $]\left[\mathrm{NTf}_{2}\right] ;{ }^{30}$ (gray) $-\left[\mathrm{C}_{\mathrm{N}-1} \mathrm{C}_{1}\right.$ im $]\left[\mathrm{NTf}_{2}\right](\mathrm{N}=3-9,11$, and 13); ${ }^{29}$ and $\bigcirc$ (blue) $-\left[\mathrm{C}_{\mathrm{N} / 2} \mathrm{C}_{\mathrm{N} / 2}\right.$ im] $\left[\mathrm{NTf}_{2}\right]\left(\mathrm{N}=4,6,8,10\right.$, and 12). ${ }^{43}$ This work: $($ green $)-\left[\mathrm{C}_{\mathrm{N} / 2} \mathrm{C}_{\mathrm{N} / 2} \mathrm{im}\right]\left[\mathrm{NTf}_{2}\right](\mathrm{N}=14,16,18$, and 20). Critical Alkyl Length (CAL), $\left[\mathrm{C}_{6} \mathrm{C}_{6}\right.$ im] $\left[\mathrm{NTf}_{2}\right]$.

In Figure 2(b), a gradual linear increase of $(1.8 \pm 0.1) \mathrm{kJ}$ $\mathrm{mol}^{-1}$ per methylene group, $-\mathrm{CH}_{2}-$, of $\Delta_{1}^{\mathrm{g}} G_{\mathrm{m}}^{\mathrm{o}}(298.15 \mathrm{~K})$, from $\left[\mathrm{C}_{4} \mathrm{C}_{4} \mathrm{im}\right]\left[\mathrm{NTf}_{2}\right]$ to $\left[\mathrm{C}_{7} \mathrm{C}_{7} \mathrm{im}\right]\left[\mathrm{NTf}_{2}\right]$, is observed, similar to the one found for the asymmetric ionic liquids, $\left[\mathrm{C}_{\mathrm{N}-1} \mathrm{C}_{1} \mathrm{im}\right]\left[\mathrm{NTf}_{2}\right]$. However, starting from $\left[\mathrm{C}_{6} \mathrm{C}_{6} \mathrm{im}\right]\left[\mathrm{NTf}_{2}\right]$ a decrease on the contribution per $-\mathrm{CH}_{2}-$ group of $(0.8 \pm 0.2)$ $\mathrm{kJ} \mathrm{mol}^{-1}$, with a clear odd-even effect on the standard molar Gibbs energies is observed, with higher $\Delta_{1}^{\mathrm{g}} G_{\mathrm{m}}^{\mathrm{o}}(298.15 \mathrm{~K})$ (lower volatility) values for the odd numbered ionic liquids, $\left[\mathrm{C}_{7} \mathrm{C}_{7} \mathrm{im}\right]\left[\mathrm{NTf}_{2}\right]$ and $\left[\mathrm{C}_{9} \mathrm{C}_{9} \mathrm{im}\right]\left[\mathrm{NTf}_{2}\right]$. Considering the associated uncertainty the volatility is similar, at $T=298.15 \mathrm{~K}$, between $\left[\mathrm{C}_{7} \mathrm{C}_{7} \mathrm{im}\right]\left[\mathrm{NTf}_{2}\right]$ with $\left[\mathrm{C}_{8} \mathrm{C}_{8} \mathrm{im}\right]\left[\mathrm{NTf}_{2}\right]$, and between $\left[\mathrm{C}_{9} \mathrm{C}_{9} \mathrm{im}\right]\left[\mathrm{NTf}_{2}\right]$ with $\left[\mathrm{C}_{10} \mathrm{C}_{10} \mathrm{im}\right]\left[\mathrm{NTf}_{2}\right]$. This can be rationalized based on the enthalpic and entropic contributions to the volatility of the ionic liquids. Briefly the significantly higher volatility of the symmetric series compared with the asymmetric is clearly driven by their lower enthalpy of va- porization (for the same number of carbons) that is an indication of a differentiation on their nanostructuration with a lower cohesive energy and a higher liquid disorder. In the present work, the discussion will focus on the symmetric ionic liquids with longer alkyl chains, since the rest of the series, $\left[\mathrm{C}_{\mathrm{N} / 2} \mathrm{C}_{\mathrm{N} / 2} \mathrm{im}\right]\left[\mathrm{NTf}_{2}\right]$ (with $\mathrm{N}=2,4,6,8,10$, and 12), were already addressed in the literature. ${ }^{30,43}$

Figures 3 and 4 show the graphic representations of the standard molar enthalpies and entropies of vaporization at reference temperatures, $T=460 \mathrm{~K}$ and $T=298.15 \mathrm{~K}$.

In both thermodynamic properties, enthalpies and entropies of vaporization, a trend shift on the odd-even effect along the symmetric ionic liquids was found. Starting from $\left[\mathrm{C}_{6} \mathrm{C}_{6} \mathrm{im}\right]\left[\mathrm{NTf}_{2}\right]$ an intensification of the odd-even effect is observed, with higher enthalpies and entropies of vaporization for the odd numbered ionic liquids, $\left[\mathrm{C}_{7} \mathrm{C}_{7} \mathrm{im}\right]\left[\mathrm{NTf}_{2}\right]$ and $\left[\mathrm{C}_{9} \mathrm{C}_{9} \mathrm{im}\right]\left[\mathrm{NTf}_{2}\right]$. A similar, while less pronounced, odd-even effect was observed for the symmetric ionic liquids with lower alkyl chain length, $\left[\mathrm{C}_{\mathrm{N} / 2} \mathrm{C}_{\mathrm{N} / 2} \mathrm{im}\right]\left[\mathrm{NTf}_{2}\right]$ (with $\mathrm{N}=4,6,8$, 10 , and 12), ${ }^{43}$ where $\left[\mathrm{C}_{3} \mathrm{C}_{3} \mathrm{im}\right]\left[\mathrm{NTf}_{2}\right]$ and $\left[\mathrm{C}_{5} \mathrm{C}_{5} \mathrm{im}\right]\left[\mathrm{NTf}_{2}\right]$ presented higher enthalpies and entropies of vaporization. ${ }^{43}$ This effect is related with the predominant orientation of the terminal methyl group of the alkyl chain to the imidazolium ring and their influence in the cation-anion interaction. ${ }^{33,34,43}$ Analogous to the observed in the crystal packing for other alkyl series, the orientation of the terminal groups is determinant for the molecular interpretation of the even-odd effect. ${ }^{62,63}$ This effect is expected to disappear or be very small in isotropic systems. In fact the appearance of the evenodd effect in ionic liquids is highly relevant as a support for the existence of nanostructuration in the liquid phase as well as an indication that the nanostructuration becomes more significant with the alkyl chain size increase.

Using the same nomenclature adopted in the previous works, ${ }^{29,30,38}$ we can consider that from $\left[\mathrm{C}_{2} \mathrm{C}_{2} \mathrm{im}\right]\left[\mathrm{NTf}_{2}\right]$ to $\left[\mathrm{C}_{6} \mathrm{C}_{6} \mathrm{im}\right]\left[\mathrm{NTf}_{2}\right]$, the compounds belong to "Region $\mathrm{A}$," and from $\left[\mathrm{C}_{6} \mathrm{C}_{6} \mathrm{im}\right]\left[\mathrm{NTf}_{2}\right]$ to $\left[\mathrm{C}_{10} \mathrm{C}_{10} \mathrm{im}\right]\left[\mathrm{NTf}_{2}\right]$, to "Region B." In the $\left[\mathrm{C}_{2} \mathrm{C}_{2} \mathrm{im}\right]\left[\mathrm{NTf}_{2}\right]$ to $\left[\mathrm{C}_{6} \mathrm{C}_{6} \mathrm{im}\right]\left[\mathrm{NTf}_{2}\right]$, "Region A," $\Delta_{\mathrm{l}}^{\mathrm{g}} H_{\mathrm{m}}^{\mathrm{o}}(298.15 \mathrm{~K})$ increases $(3.6 \pm 0.2) \mathrm{kJ} \mathrm{mol}^{-1}$ per methylene group, $-\mathrm{CH}_{2}-$, added to the alkyl side chains of the cation. This is followed by a decrease of the $-\mathrm{CH}_{2}-$ group contribution of $(1.2 \pm 0.5) \mathrm{kJ} \mathrm{mol}^{-1}$, from $\left[\mathrm{C}_{6} \mathrm{C}_{6} \mathrm{im}\right]\left[\mathrm{NTf}_{2}\right]$ to $\left[\mathrm{C}_{10} \mathrm{C}_{10} \mathrm{im}\right]\left[\mathrm{NTf}_{2}\right]$, "Region $\mathrm{B}$," which indicates a decrease of the $-\mathrm{CH}_{2}-$ group contribution for the cohesive energies in "Region B." This could be related with the higher separations between the charged region, due to the steric hindrance arising from the longer alkyl chains present in both sides of the cation, from $\left[\mathrm{C}_{6} \mathrm{C}_{6} \mathrm{im}\right]\left[\mathrm{NTf}_{2}\right]$ to $\left[\mathrm{C}_{10} \mathrm{C}_{10} \mathrm{im}\right]\left[\mathrm{NTf}_{2}\right]$, leading to a decline on the overall electrostatic interactions.

The entropy of vaporization, $\Delta_{1}^{\mathrm{g}} S_{\mathrm{m}}^{\mathrm{o}}(298.15 \mathrm{~K})$, profile along the series shown in Figure 4(b), is analogous to the observed for the enthalpies of vaporization. In addition to the intensification of the odd-even effect from "Region A" to "Region B," it can be observed a decrease of the contribution per $-\mathrm{CH}_{2}-$ group on the $\Delta_{1}^{\mathrm{g}} S_{\mathrm{m}}^{\mathrm{o}}(298.15 \mathrm{~K})$, from $\left[\mathrm{C}_{2} \mathrm{C}_{2} \mathrm{im}\right]\left[\mathrm{NTf}_{2}\right]$ to $\left[\mathrm{C}_{6} \mathrm{C}_{6} \mathrm{im}\right]\left[\mathrm{NTf}_{2}\right]$ of $(7.5 \pm 0.4) \mathrm{J} \mathrm{K}^{-1}$ $\mathrm{mol}^{-1}$, and from $\left[\mathrm{C}_{6} \mathrm{C}_{6} \mathrm{im}\right]\left[\mathrm{NTf}_{2}\right]$ to $\left[\mathrm{C}_{10} \mathrm{C}_{10} \mathrm{im}^{\mathrm{m}}\right]\left[\mathrm{NTf}_{2}\right]$ of $(1.2 \pm 0.9) \mathrm{J} \mathrm{K}^{-1} \mathrm{~mol}^{-1}$. Considering that the absolute standard entropies in the gaseous phase increase linearly, 
the observed change should be due to an intensification of the increase of the absolute standard entropies in the liquid phase, starting from $\left[\mathrm{C}_{6} \mathrm{C}_{6} \mathrm{im}\right]\left[\mathrm{NTf}_{2}\right]$, in agreement with the literature. ${ }^{33}$

For the same number of carbons in the alkyl chain, the observed higher volatility of the symmetric ionic liquids than the asymmetric is ruled by the lower enthalpies of vaporization of the symmetric series. The lower enthalpies of vaporization of the symmetric series are only partial entropically compensated leading to a volatility increase reflecting the steric hindrance arising from the alkyl chains present in both sides of the cation.

\section{FINAL REMARKS}

In a previous work reporting a volatility study for the asymmetric ionic liquids, $\left[\mathrm{C}_{\mathrm{N}-1} \mathrm{C}_{1} \mathrm{im}\right]\left[\mathrm{NTf}_{2}\right]$, a shift in the enthalpies and entropies of vaporization profiles with the alkyl side chain length was observed, which was shown to be related to a change in the molecular structure organization of the liquid phase, around $\left[\mathrm{C}_{6} \mathrm{C}_{1} \mathrm{im}\right]\left[\mathrm{NTf}_{2}\right]$. The symmetry of the ionic liquid cation, changes dramatically the thermophysical properties, as it was already shown in the literature. ${ }^{30,33,34,43,64}$ In fact, only recently the extended series of $\left[\mathrm{C}_{\mathrm{N} / 2} \mathrm{C}_{\mathrm{N} / 2} \mathrm{im}\right]\left[\mathrm{NTf}_{2}\right]$ ionic liquids was fully studied concerning the heat capacities, viscosities, densities and the liquid structure using SWAX ${ }^{33,34,64}$ and more recently using molecular dynamics simulations, ${ }^{9}$ and two regions were identified, with a shift around $\left[\mathrm{C}_{6} \mathrm{C}_{6} \mathrm{im}\right]\left[\mathrm{NTf}_{2}\right]$. Above $\left[\mathrm{C}_{6} \mathrm{C}_{6} \mathrm{im}\right]\left[\mathrm{NTf}_{2}\right]$ the symmetric ionic liquids presents lower enthalpies and entropies of vaporization than what would be expected from the shorter alkyl chain trend, with an accentuated odd-even effect, presenting higher values for the odd numbered ionic liquids, $\left[\mathrm{C}_{7} \mathrm{C}_{7} \mathrm{im}\right]\left[\mathrm{NTf}_{2}\right]$ and $\left[\mathrm{C}_{9} \mathrm{C}_{9} \mathrm{im}\right]\left[\mathrm{NTf}_{2}\right]$. The profile of the two regions found for the thermodynamic properties of vaporization for the extended series of $\left[\mathrm{C}_{\mathrm{N} / 2} \mathrm{C}_{\mathrm{N} / 2} \mathrm{im}\right]\left[\mathrm{NTf}_{2}\right]$, is in agreement with the expected effect arising from the nanostructuration in ionic liquids. ${ }^{9}$ It is well established that in the liquid phase of ionic liquids, the polar regions tend to organize themselves in order to enhance the electrostatic interactions between the cation and anion and the alkyl chains of the cation for a non-polar segregated network. ${ }^{5,8,9,31,32}$ The segregation of the non-polar nanostructured regions leads to an increase of the contribution of the methylene group, to the absolute entropy of the liquid as well as to the cohesive energy, due to the overlapping of the decreasing electrostatic interaction potential by the increasing van der Waals potential. The results and discussion presented in this work is a strong support and indication that for the symmetric series, $\left[\mathrm{C}_{\mathrm{N} / 2} \mathrm{C}_{\mathrm{N} / 2} \mathrm{im}\right]\left[\mathrm{NTf}_{2}\right]$, the limit for the beginning of the nanostructuration/alkyl chain segregation is $\left[\mathrm{C}_{6} \mathrm{C}_{6} \mathrm{im}\right]\left[\mathrm{NTf}_{2}\right]$, presenting the same size for the longer alkyl chain than the asymmetric series where the limit was found to be $\left[\mathrm{C}_{6} \mathrm{C}_{1} \mathrm{im}\right]\left[\mathrm{NTf}_{2}\right]$.

\section{ACKNOWLEDGMENTS}

Thanks are due to Fundação para a Ciência e Tecnologia (FCT), Lisbon, Portugal and to FEDER for financial support to Centro de Investigação em Química, University of Porto through the project Pest-C/QUI/UI0081/2013, and CICECO, University of Aveiro, through the project PestC/CTM/LA0011/2013. M. A. A. Rocha acknowledges the financial support from FCT and the European Social Fund (ESF) under the Community Support Framework (CSF) for the award of a Ph.D. Research Grant, SFRH/BD/60513/2009.

${ }^{1}$ M. J. Earle, J. M. S. S. Esperança, M. A. Gilea, J. N. C. Lopes, L. P. N. Rebelo, J. W. Magee, K. R. Seddon, and J. A. Widegren, Nature (London) 439, 831 (2006).

${ }^{2}$ D. H. Zaitsau, G. J. Kabo, A. A. Strechan, Y. U. Paulechka, A. Tschersich, S. P. Verevkin, and A. Heintz, J. Phys. Chem. A 110, 7303 (2006).

${ }^{3}$ Y. U. Paulechka, D. H. Zaitsau, G. J. Kabo, and A. A. Strechan, Thermochim. Acta 439, 158 (2005).

${ }^{4}$ L. M. N. B. F. Santos, J. N. C. Lopes, J. A. P. Coutinho, J. M. S. S. Esperança, L. R. Gomes, I. M. Marrucho, and L. P. N. Rebelo, J. Am. Chem. Soc. 129, 284 (2007).

${ }^{5}$ J. N. A. Canongia Lopes and A. A. H. Pádua, J. Phys. Chem. B 110, 3330 (2006).

${ }^{6}$ F. Dommert, K. Wendler, R. Berger, L. Delle Site, and C. Holm, ChemPhysChem 13, 1625 (2012).

${ }^{7}$ J. M. S. S. Esperança, J. N. Canongia Lopes, M. Tariq, L. M. N. B. F. Santos, J. W. Magee, and L. P. N. Rebelo, J. Chem. Eng. Data 55, 3 (2010).

${ }^{8}$ K. Shimizu, C. E. S. Bernardes, and J. N. Canongia Lopes, J. Phys. Chem. B 118, 567 (2014).

${ }^{9}$ C. E. S. Bernardes, K. Shimizu, A. I. M. C. Lobo Ferreira, L. M. N. B. F. Santos, and J. N. Canongia Lopes, J. Phys. Chem. B 118, 6885 (2014).

${ }^{10}$ A. Deyko, K. R. J. Lovelock, J.-A. Corfield, A. W. Taylor, P. N. Gooden, I. J. Villar-Garcia, P. Licence, R. G. Jones, V. G. Krasovskiy, E. A. Chernikova, and L. M. Kustov, Phys. Chem. Chem. Phys. 11, 8544 (2009).

${ }^{11}$ K. R. J. Lovelock, A. Deyko, J.-A. Corfield, P. N. Gooden, P. Licence, and R. G. Jones, Chemphyschem 10, 337 (2009).

${ }^{12}$ J. P. Armstrong, C. Hurst, R. G. Jones, P. Licence, K. R. J. Lovelock, C. J. Satterley, and I. J. Villar-Garcia, Phys. Chem. Chem. Phys. 9, 982 (2007).

${ }^{13}$ S. P. Verevkin, D. H. Zaitsau, V. N. Emel'yanenko, R. V. Ralys, A. V. Yermalayeu, and C. Schick, J. Chem. Thermodyn. 54, 433 (2012).

${ }^{14}$ K. Fumino, A. Wulf, S. P. Verevkin, A. Heintz, and R. Ludwig, Chemphyschem 11, 1623 (2010).

${ }^{15}$ S. D. Chambreau, G. L. Vaghjiani, A. To, C. Koh, D. Strasser, O. Kostko, and S. R. Leone, J. Phys. Chem. B 114, 1361 (2010).

${ }^{16}$ C. Wang, H. Luo, H. Li, and S. Dai, Phys. Chem. Chem. Phys. 12, 7246 (2010)

${ }^{17}$ A. Deyko, S. G. Hessey, P. Licence, E. A. Chernikova, V. G. Krasovskiy, L. M. Kustov, and R. G. Jones, Phys. Chem. Chem. Phys. 14, 3181 (2012).

${ }^{18}$ S. P. Verevkin, R. V. Ralys, D. H. Zaitsau, V. N. Emel'yanenko, and C. Schick, Thermochim. Acta 538, 55 (2012).

${ }^{19}$ M. S. Kelkar and E. J. Maginn, J. Phys. Chem. B 111, 9424 (2007).

${ }^{20}$ F. Heym, B. J. M. Etzold, C. Kern, and A. Jess, Green Chem. 13, 1453 (2011).

${ }^{21}$ S. P. Verevkin, D. H. Zaitsau, V. N. Emel'yanenko, R. V. Ralys, A. V. Yermalayeu, and C. Schick, Thermochim. Acta 562, 84 (2013).

${ }^{22}$ D. Strasser, F. Goulay, M. S. Kelkar, E. J. Maginn, and S. R. Leone, J. Phys. Chem. A 111, 3191 (2007).

${ }^{23}$ V. N. Emel'yanenko, S. P. Verevkin, A. Heintz, J.-A. Corfield, A. Deyko, K. R. J. Lovelock, P. Licence, and R. G. Jones, J. Phys. Chem. B 112, 11734 (2008).

${ }^{24}$ J. P. Leal, M. E. M. da Piedade, J. N. Canongia Lopes, A. A. Tomaszowska, J. M. S. S. Esperança, L. P. N. Rebelo, and K. R. Seddon, J. Phys. Chem. B 113, 3491 (2009).

${ }^{25}$ J. P. Leal, J. M. S. S. Esperança, M. E. M. da Piedade, J. N. C. Lopes, L. P. N. Rebelo, and K. R. Seddon, J. Phys. Chem. A 111, 6176 (2007).

${ }^{26}$ J. H. Gross, J. Am. Soc. Mass Spectrom. 19, 1347 (2008).

${ }^{27}$ V. V. Chaban and O. V. Prezhdo, J. Phys. Chem. Lett. 3, 1657 (2012).

${ }^{28}$ B. A. D. Neto, E. C. Meurer, R. Galaverna, B. J. Bythell, J. Dupont, R. G. Cooks, and M. N. Eberlin, J. Phys. Chem. Lett. 3, 3435 (2012).

${ }^{29}$ M. A. A. Rocha, C. F. R. A. C. Lima, L. R. Gomes, B. Schröder, J. A. P. Coutinho, I. M. Marrucho, J. M. S. S. Esperança, L. P. N. Rebelo, K. Shimizu, J. N. C. Lopes, and L. M. N. B. F. Santos, J. Phys. Chem. B 115, 10919 (2011).

${ }^{30}$ M. A. A. Rocha, F. M. S. Ribeiro, B. Schröder, J. A. P. Coutinho, and L. M. N. B. F. Santos, J. Chem. Thermodyn. 68, 317 (2014). 
${ }^{31}$ K. Shimizu, M. F. Costa Gomes, A. A. H. Pádua, L. P. N. Rebelo, and J. N. Canongia Lopes, J. Mol. Struct.: THEOCHEM 946, 70 (2010).

${ }^{32}$ M. F. C. Gomes, J. N. C. Lopes, and A. A. H. Padua, Top. Curr. Chem. 290, 161 (2010).

${ }^{33}$ M. A. A. Rocha, C. M. S. S. Neves, M. G. Freire, O. Russina, A. Triolo, J. A. P. Coutinho, and L. M. N. B. F. Santos, J. Phys. Chem. B 117, 10889 (2013).

${ }^{34}$ M. A. A. Rocha, J. A. P. Coutinho, and L. M. N. B. F. Santos, J. Chem. Phys. 139, 104502 (2013).

${ }^{35}$ S. P. Verevkin, D. H. Zaitsau, V. N. Emel'yanenko, A. V. Yermalayeu, C. Schick, H. Liu, E. J. Maginn, S. Bulut, I. Krossing, and R. Kalb, J. Phys. Chem. B 117, 6473 (2013).

${ }^{36}$ M. G. Freire, C. M. S. S. Neves, J. N. Canongia Lopes, I. M. Marrucho, J. A. P. Coutinho, and L. P. N. Rebelo, J. Phys. Chem. B 116, 7660 (2012).

${ }^{37}$ H. Passos, M. P. Trindade, T. S. M. Vaz, L. P. da Costa, M. G. Freire, and J. A. P. Coutinho, Sep. Purif. Technol. 108, 174 (2013).

${ }^{38}$ M. A. A. Rocha, M. Bastos, J. A. P. Coutinho, and L. M. N. B. F. Santos, J. Chem. Thermodyn. 53, 140 (2012).

${ }^{39}$ M. A. A. Rocha, F. M. S. Ribeiro, A. I. M. C. L. Ferreira, J. A. P. Coutinho, and L. M. N. B. F. Santos, J. Mol. Liq. 188, 196 (2013).

${ }^{40}$ M. Tariq, P. J. Carvalho, J. A. P. Coutinho, I. M. Marrucho, J. N. C. Lopes, and L. P. N. Rebelo, Fluid Phase Equilib. 301, 22 (2011).

${ }^{41}$ H. Tokuda, K. Hayamizu, K. Ishii, M. A. B. H. Susan, and M. Watanabe, J. Phys. Chem. B 109, 6103 (2005).

${ }^{42}$ S. Coleman, R. Byrne, S. Minkovska, and D. Diamond, J. Phys. Chem. B 113, 15589 (2009).

${ }^{43}$ M. A. A. Rocha, J. A. P. Coutinho, and L. M. N. B. F. Santos, J. Phys. Chem. B 116, 10922 (2012).

${ }^{44}$ L. M. N. B. F. Santos, L. M. S. S. Lima, C. F. R. A. C. Lima, F. D. Magalhães, M. C. Torres, B. Schröder, and M. A. V. Ribeiro da Silva, J. Chem. Thermodyn. 43, 834 (2011).

${ }^{45}$ M. E. Wieser and M. Berglund, Pure Appl. Chem. 81, 2131 (2009).

${ }^{46}$ E. C. W. Clarke and D. N. Glew, Trans. Faraday Soc. 62, 539 (1966).

${ }^{47}$ P. J. Mohr, B. N. Taylor, and D. B. Newell, Rev. Mod. Phys. 84, 1527 (2012).
${ }^{48}$ M. Ahrenberg, M. Brinckmann, J. W. P. Schmelzer, M. Beck, C. Schmidt, O. Kessler, U. Kragl, S. P. Verevkin, and C. Schick, Phys. Chem. Chem. Phys. 16, 2971 (2014).

${ }^{49}$ S. P. Verevkin, D. H. Zaitsau, V. N. Emelyanenko, and A. Heintz, J. Phys. Chem. B 115, 12889 (2011).

${ }^{50}$ D. H. Zaitsau, S. P. Verevkin, V. N. Emel'yanenko, and A. Heintz, Chemphyschem 12, 3609 (2011).

${ }^{51}$ V. N. Emel'yanenko, S. P. Verevkin, and A. Heintz, J. Am. Chem. Soc. 129, 3930 (2007).

${ }^{52}$ S. P. Verevkin, V. N. Emel'yanenko, D. H. Zaitsau, A. Heintz, C. D. Muzny, and M. Frenkel, Phys. Chem. Chem. Phys. 12, 14994 (2010).

${ }^{53}$ Y. U. Paulechka, G. J. Kabo, and V. N. Emel'yanenko, J. Phys. Chem. B 112, 15708 (2008).

${ }^{54}$ A. V. Blokhin, Y. U. Paulechka, and G. J. Kabo, J. Chem. Eng. Data 51, 1377 (2006).

${ }^{55}$ A. V. Blokhin, Y. U. Paulechka, A. A. Strechan, and G. J. Kabo, J. Phys. Chem. B 112, 4357 (2008).

${ }^{56}$ Y. U. Paulechka, A. V. Blokhin, G. J. Kabo, and A. A. Strechan, J. Chem. Thermodyn. 39, 866 (2007).

${ }^{57}$ Y. Shimizu, Y. Ohte, Y. Yamamura, and K. Saito, Chem. Phys. Lett. 470, 295 (2009).

${ }^{58}$ Y. U. Paulechka, A. G. Kabo, A. V. Blokhin, G. J. Kabo, and M. P. Shevelyova, J. Chem. Eng. Data 55, 2719 (2010).

${ }^{59}$ Y. U. Paulechka, J. Phys. Chem. Ref. Data 39, 033108 (2010).

${ }^{60}$ G. J. Kabo, A. V. Blokhin, Y. U. Paulechka, A. G. Kabo, M. P. Shymanovich, and J. W. Magee, J. Chem. Eng. Data 49, 453 (2004).

${ }^{61}$ K. S. Rane and J. R. Errington, J. Phys. Chem. B 118, 8734 (2014).

${ }^{62}$ J. C. S. Costa, M. Fulem, B. Schröder, J. A. P. Coutinho, M. J. S. Monte, and L. M. N. B. F. Santos, J. Chem. Thermodyn. 54, 171 (2012).

${ }^{63}$ D. G. Yablon, D. Wintgens, and G. W. Flynn, J. Phys. Chem. B 106, 5470 (2002).

${ }^{64}$ W. Zheng, A. Mohammed, L. G. Hines, D. Xiao, O. J. Martinez, R. A. Bartsch, S. L. Simon, O. Russina, A. Triolo, and E. L. Quitevis, J. Phys. Chem. B 115, 6572 (2011).

${ }^{65}$ See supplementary material at http://dx.doi.org/10.1063/1.4896704 for NMR spectra for the studied ionic liquids. 